\title{
50 Percent Cell Culture Infective Dose
}

National Cancer Institute

\section{Source}

National Cancer Institute. 50 Percent Cell Culture Infective Dose. NCI Thesaurus. Code C70534.

A potency unit defined as a minimal dose of infectious material at which preparation causes cytopathic effects (changes in the morphology and metabolism of cell culture cells, indicating cell death, due to suspected infection) in the $50 \%$ of the cell culturecontaining vessels inoculated with that dilution of infectious material. 